\title{
Enhancing Mungbean (Vigna radiata L.) Productivity, Soil Health and Profitability through Conjoint use of Rhizobium and PGPR
}

\begin{abstract}
Background: Grain legumes are considered as an important group of food crops that can play a vital role to address national food and nutritional security and also tackle environmental challenges. They are known as the basis for an ecologically-sound, farmerfocused agricultural development effort and an important component of sustainable farming systems. Biofertilizers, being a cheap and environment friendly source of plant nutrients assume a special significance in supplying the plant nutrients under the present context of indiscriminate use and high costs of chemical fertilizers. Biofertilizers could be a good alternative to supplement the chemical fertilizers.

Methods: A field experiment was carried out at Pantnagar in Mollisols during 2017-18 and 2018-19 to study the performance of Rhizobium sp. and plant growth promoting rhizobacteria (PGPR) inoculation in mungbean on productivity, soil health and economics. Result: A pronounced effect of biofertilizers application in mungbean was observed on the root nodulation, yields, nutrient uptake and soil health. Co-inoculation of Rhizobium and PGPR significantly increased the nodule number, nodule dry weight, plant dry weight, grain yield, straw yield, $\mathrm{N}$ and $\mathrm{P}$ uptake in mungbean and improved soil health over the no inoculation. The study suggested that combined application of PGPR and Rhizobium sp. in mungbean is better than Rhizobium sp. alone in increasing crop yields, soil health and farmer's profit.
\end{abstract}

Key words: Biofertilizers, Co-inoculation, Economics, Mungbean, Productivity, Soil health.

\section{INTRODUCTION}

Among the cultivated crops of the world, grain legumes represent an important component of food crops with annual global production of 79 million metric tonnes (Joshi and Rao, 2017). They have long been considered as a good source of protein, thus play a crucial role in healthy diets, sustainable food production and in food security. Besides, legumes also have several positive impacts on soil health maintenance through processes of biological nitrogen fixation (BNF) and nutrient cycling. Mungbean (Vigna radiata L.) is one of the major grain legumes of India. It is a short duration crop and fits well in various cropping systems. It can also be grown as a catch crop during kharif season. It is cultivated on 4.25 million hectares area with the production of 2.41 million tonnes and average productivity of $567 \mathrm{~kg} \mathrm{ha}^{-1}$ (Anonymous, 2019). Mungbean, like many other legumes, is capable of utilizing and fixing the atmospheric nitrogen $\left(\mathrm{N}_{2}\right)$ in association of soil bacteria of genus Rhizobium or Bradyrhizobium (Mondal et al. 2013). Combined inoculation of PGPR with rhizobia in grain legumes has received much attention in recent years mainly because of their positive effects on nodulation, $\mathrm{N}_{2}$ fixation and yield of legume crops (Dudeja et al. 2011). The combined application of Rhizobium $\mathrm{sp}$. with PGPR is advocated to obtain the benefits of both $\mathrm{N}_{2}$ fixation by rhizobia and plant growth promotion through plant growth promoting (PGP) traits of PGPR (Bhattacharya and Jha, 2012; Kaur et al. 2015). However, the compatibility
Department of Soil Science, G.B. Pant University of Agriculture and Technology, Pantnagar-263 145, Uttarakhand, India.

Corresponding Author: Ramesh Chandra, Department of Soil Science, G.B. Pant University of Agriculture and Technology, Pantnagar-263 145, Uttarakhand, India.

Email: rc.pantnagar@gmail.com

How to cite this article: Neha, Chandra, R., Pareek, N., Raverkar, K.P. (2021). Enhancing Mungbean (Vigna radiata L.) Productivity, Soil Health and Profitability through Conjoint use of Rhizobium and PGPR. Legume Research. DOI: 10.18805/LR-4552.

Submitted: 25-11-2020 Accepted: 07-04-2021 Online: 29-04-2021

of these microorganisms needs to be evaluated because of the possibility of the antagonistic interactions among them. Present study communicates the findings of two years study on the performance of conjoint use of Rhizobium sp. and PGPR in mungbean on symbiotic performance, yield, nutrient uptake, soil fertility and economics with aim of making a practical recommendation for promotion of biofertilizers to minimize the use of costly chemical fertilizers and reducing the environmental pollution.

\section{MATERIALS AND METHODS}

A field experiment was conducted during kharif seasons of 2017-18 and 2018-19 at Norman E. Borlaug Crop Research Centre of G.B. Pant University of Agriculture and Technology, 
Pantnagar $\left(29.8^{\circ} \mathrm{N}, 73.9^{\circ} \mathrm{E}, 243.8 \mathrm{~m}\right.$ above mean sea level). The experimental soil was Sandy loam of $\mathrm{pH} 7.43$, E.C. 0.48 $\mathrm{dS} \mathrm{m} \mathrm{m}^{-1}$ having $7.9 \mathrm{~g} \mathrm{~kg}^{-1}$ Organic $\mathrm{C}$ and 228.3, 23.4 and 218.1 $\mathrm{kg} \mathrm{ha}^{-1}$ available N, P and K, respectively. Treatments consisted of seed inoculation with Rhizobium sp. (MR-14), PGPR (Bacillus cereus, NE-10), Rhizobium sp. + PGPR, RDF (20 kg N + 40 $\mathrm{kg} \mathrm{P}_{2} \mathrm{O}_{5} \mathrm{ha}^{-1}$ ) and uninoculated control. The experiment was laid out in split plot design in plots of $2.4 \mathrm{~m} \times 3.0 \mathrm{~m}$ size in 3 replications during both the years. The test crop variety was Pant Mung 5. Inoculation was done through seed treatment using carrier based inoculant at the rate of $20 \mathrm{~g} \mathrm{~kg}^{-1}$ seed at the time of sowing. Dual inoculation was done by mixing the required quantity of each Rhizobium sp. and PGPR inoculants. RDF treatment was executed through basal application of 20 $\mathrm{kg} \mathrm{N}$ and $40 \mathrm{~kg} \mathrm{P}_{2} \mathrm{O}_{5}$ ha $^{-1}$ through urea and single super phosphate (SSP), respectively. The crop was raised following recommended agronomic practices.

Root nodulation was recorded at 30 and 45 days after sowing (DAS) from ten randomly selected plants. Plants were uprooted along with soil core of about $25 \mathrm{~cm}$, the adhering soil on roots was gently washed off, root nodules were removed and counted. The dry weight of detached nodules and plants was recorded after drying in hot air oven at $70^{\circ} \mathrm{C}$ to constant weight. The grain and straw yields were recorded after harvesting the crop. The $\mathrm{N}$ and $\mathrm{P}$ content in grain and straw was estimated after finely grinding to 40 mesh following the methods as described by Page et al. (1982) and their uptake were computed. Soil samples of $0-15 \mathrm{~cm}$ depth were collected from individual plots after harvesting the crop. Soil samples were air-dried, processed to pass through 2-mm sieve and analyzed for organic $\mathrm{C}$, mineral $\mathrm{N}$ (2 $\mathrm{M} \mathrm{KCl}$ extractable), available $\mathrm{N}\left(0.32 \%\right.$ alkaline $\mathrm{KMnO}_{4}$ oxidizable), available $\mathrm{P}\left(0.5 \mathrm{M} \mathrm{NaHCO}_{3}\right.$ extractable $)$ and available $\mathrm{K}\left(1 \mathrm{~N} \mathrm{NH}_{4} \mathrm{OAc}\right.$; $\mathrm{pH} 7.0$ extractable) following the methods described by Page et al. (1982). The experimental data were statistically analyzed by applying analysis of variance and treatments were compared using the F-test by calculating the critical difference at $5 \%$ level of significance.

\section{RESULTS AND DISCUSSION Nodulation}

Seed inoculation with Rhizobium and PGPR in mungbean, individually and in combination, improved the number and dry weight of root nodules significantly (Table 1 ). Pooled mean of both the years indicated that Rhizobium inoculation alone increased the nodule number significantly, by 41.3 and $25.8 \%$, and nodule dry weight, by 38.3 and $19.7 \%$ at 30 and 45 DAS over the uninoculated control, respectively. PGPR alone also increased nodule number and nodule dry weight of 18.7 and $30.5 \%$ at 30 DAS and 14.3 and $16.3 \%$ at 45 DAS over the uninoculated control, respectively. Combined inoculation of Rhizobium and PGPR further enhanced the number and dry weight of root nodules registering 20.7 and $16.7 \%$ more nodule number and 9.0 and $3.1 \%$ more nodule dry weight over Rhizobium alone inoculation at 30 and 45 DAS, respectively. The positive impacts of combined application of Rhizobium and PGPR in mungbean have also been reported by Bansal (2009). The increase in root nodules may be attributed to the enhancement in the effective rhizobial population in rhizosphere following inoculation. The PGPR (B. cereus) used in the present study was a potential $P$ solubilizer (Rana et al. 2015), which possibly allowed the synthesis of more nodule tissue and $\mathrm{N}_{2}$ fixation in comparison to uninoculated treatment. The results are in agreement with the report of Stajkovic et al. (2011) who reported that the enhancement in nodule number and nodule dry weight in common bean due to the coinoculation was because of the expansion in root length and mass, thus responsible for more number of active sites for nodulation by the rhizobia.

\section{Plant dry weight}

Inoculation in mungbean with Rhizobium sp. and PGPR, alone and in combination, also increased the mean plant dry weight in both the years (Table 2). Sole inoculation of Rhizobium and PGPR produced significantly higher mean plant dry weight, by 35.3 and $23.7 \%$ at 30 DAS and 17.0 and $11.1 \%$ at 45 DAS over the uninoculated, respectively. The maximum mean plant dry weight of both the years was recorded with conjoint use of Rhizobium + PGPR, being 13.0 and $19.3 \%$ more over Rhizobium alone inoculation at 30 and 45 DAS, respectively. It could be attributed to the synergistic interaction between co-inoculated Rhizobium and PGPR leading to the increase in the plant nutrition and growth (Khanna and Sharma, 2011).

\section{Grain and Straw yields}

Although, treatment of recommended fertilizer dose produced the highest grain and straw yields in both the

Table 1: Effect of different inoculation treatments on number and dry weight of root nodules at different intervals.

\begin{tabular}{|c|c|c|c|c|c|c|c|c|c|c|c|c|}
\hline \multirow{3}{*}{ Treatment } & \multicolumn{6}{|c|}{ Nodule number plant $^{-1}$} & \multicolumn{6}{|c|}{ Nodule dry weight $\left(\mathrm{mg} \mathrm{plant}^{-1}\right)$} \\
\hline & \multicolumn{3}{|c|}{30 DAS } & \multicolumn{3}{|c|}{45 DAS } & \multicolumn{3}{|c|}{30 DAS } & \multicolumn{3}{|c|}{45 DAS } \\
\hline & 2017 & 2018 & $\begin{array}{l}\text { Pooled } \\
\text { mean }\end{array}$ & 2017 & 2018 & $\begin{array}{c}\text { Pooled } \\
\text { mean }\end{array}$ & 2017 & 2018 & $\begin{array}{l}\text { Pooled } \\
\text { mean }\end{array}$ & 2017 & 2018 & $\begin{array}{r}\text { Pooled } \\
\text { mean }\end{array}$ \\
\hline Uninoculated control & 7.4 & 7.6 & 7.5 & 14.6 & 15.0 & 14.7 & 7.87 & 8.11 & 7.99 & 15.47 & 15.76 & 15.61 \\
\hline Rhizobium (MR 14) & 10.1 & 11.0 & 10.6 & 18.2 & 18.9 & 18.5 & 10.84 & 11.27 & 11.05 & 18.51 & 18.85 & 18.69 \\
\hline PGPR(NE 10) & 8.5 & 9.2 & 8.9 & 16.6 & 17.2 & 16.8 & 10.22 & 10.64 & 10.43 & 17.98 & 18.32 & 18.15 \\
\hline Rhizobium + PGPR & 12.3 & 13.3 & 12.8 & 21.1 & 22.1 & 21.6 & 11.74 & 12.35 & 12.05 & 19.22 & 19.58 & 19.40 \\
\hline RDF & 9.6 & 10.4 & 10.0 & 18.2 & 18.8 & 18.6 & 8.54 & 8.86 & 8.70 & 16.08 & 16.38 & 16.23 \\
\hline C.D. $(P=0.05)$ & 1.4 & 1.4 & 0.9 & 3.3 & 3.1 & 2.3 & 1.08 & 1.25 & 0.80 & 2.12 & 2.16 & 1.42 \\
\hline
\end{tabular}


years, however, it was statistically at par with dual inoculation of Rhizobium sp. + PGPR (Table 3). The latter treatment produced significantly more mean grain yield of $9.2 \%$ and numerically more mean straw yield of $11.1 \%$ over the uninoculated control. Individual inoculation of Rhizobium sp. and PGPR showed marginal increases in grain and straw yields. The symbiosis of rhizobia and legumes is well documented. It colonizes the plant root system and induces the nodule formation. However, when it was inoculated conjointly with PGPR, it allowed better nodulation and $\mathrm{N}_{2}$ fixation due to the synergistic interaction among the inoculated microorganisms as reported elsewhere (Khanna and Sharma, 2011). The beneficial effects of PGPR is also attributed to increase in root volume and number, thus enhancing the action of Rhizobium sp. by supplying biologically fixed $\mathrm{N}$ to the plant resulting in increase in grain yield (Hungria et al. 2015).

\section{$\mathbf{N}$ content and uptake}

The different inoculation treatments in mungbean significantly increased the $\mathrm{N}$ content in grain ranging from 15.1 to $31.3 \%$ during $2017-18$ and 16.4 to $33.7 \%$ during 2018-19 (Table 4). The increase in straw $\mathrm{N}$ content ranged from 16.7 to $49.5 \%$ during $2017-18$ and 20.2 to $54.9 \%$ during 2018-19 over the uninoculated control, respectively. The highest $\mathrm{N}$ content in grain and straw was obtained with combined inoculation treatment of Rhizobium + PGPR. This treatment accumulated maximum $\mathrm{N}$ in plants. Mean $\mathrm{N}$ uptake by grain and straw being 45.3 and $69.2 \%$ more over uninoculated control and 7.6 and $9.3 \%$ over Rhizobium alone inoculation. It was followed by the sole inoculation of Rhizobium and RDF treatments in $\mathrm{N}$ uptake by grain. The favourable effects of rhizobia inoculation in legumes on $\mathrm{N}$ content and its accumulation are well known due to

Table 2: Effect of biofertilizer treatments in mungbean on plant dry weight $\left(\mathrm{g} \mathrm{plant}^{-1}\right)$ at 30 and 45 days after sowing.

\begin{tabular}{|c|c|c|c|c|c|c|}
\hline \multirow{3}{*}{ Treatment } & \multicolumn{6}{|c|}{ Plant dry weight $\left(\right.$ g plant $\left.^{-1}\right)$} \\
\hline & \multicolumn{3}{|c|}{30 DAS } & \multicolumn{3}{|c|}{45 DAS } \\
\hline & 2017 & 2018 & Pooled mean & 2017 & 2018 & Pooled mean \\
\hline Uninoculated control & 2.06 & 2.23 & 2.15 & 10.37 & 10.52 & 10.45 \\
\hline Rhizobium (MR 14) & 2.76 & 3.06 & 2.91 & 12.13 & 12.34 & 12.23 \\
\hline PGPR (NE 10) & 2.53 & 2.78 & 2.66 & 11.40 & 11.81 & 11.61 \\
\hline Rhizobium + PGPR & 3.18 & 3.39 & 3.29 & 14.61 & 14.57 & 14.59 \\
\hline RDF & 2.73 & 3.01 & 2.87 & 11.82 & 12.15 & 11.99 \\
\hline C.D. $(P=0.05)$ & 0.56 & 0.67 & 0.45 & 1.35 & 1.40 & 1.09 \\
\hline
\end{tabular}

Table 3: Effect of biofertilizer treatments in mungbean on yields of mungbean.

\begin{tabular}{|c|c|c|c|c|c|c|}
\hline \multirow[b]{2}{*}{ Treatment } & \multicolumn{3}{|c|}{ Grain yield $\left(\mathrm{kg} \mathrm{ha}^{-1}\right)$} & \multicolumn{2}{|c|}{ Straw yield $\left(\mathrm{kg} \mathrm{ha}^{-1}\right)$} & \multirow[b]{2}{*}{$\begin{array}{c}\text { Pooled } \\
\text { mean }\end{array}$} \\
\hline & 2017 & 2018 & $\begin{array}{l}\text { Pooled } \\
\text { mean }\end{array}$ & 2017 & 2018 & \\
\hline Uninoculated control & 1191 & 1187 & 1189 & 1656 & 1637 & 1647 \\
\hline Rhizobium (MR 14) & 1276 & 1256 & 1266 & 1800 & 1759 & 1779 \\
\hline PGPR (NE 10) & 1214 & 1225 & 1219 & 1713 & 1704 & 1708 \\
\hline Rhizobium + PGPR & 1294 & 1306 & 1299 & 1850 & 1810 & 1830 \\
\hline RDF & 1324 & 1333 & 1328 & 1891 & 1803 & 1847 \\
\hline C.D. $(P=0.05)$ & NS & 69 & 63 & NS & NS & NS \\
\hline
\end{tabular}

Table 4: Effect of biofertilizer treatments in mungbean on $\mathrm{N}$ content and uptake by mungbean grain and straw.

\begin{tabular}{|c|c|c|c|c|c|c|c|c|c|c|}
\hline & \multicolumn{4}{|c|}{$\mathrm{N}$ content $(\%)$} & \multicolumn{6}{|c|}{$\mathrm{N}$ uptake $\left(\mathrm{kg} \mathrm{ha}^{-1}\right)$} \\
\hline & \multicolumn{2}{|c|}{ Grain } & \multicolumn{2}{|c|}{ Straw } & \multicolumn{3}{|c|}{ Grain } & \multicolumn{3}{|c|}{ Straw } \\
\hline & 2017 & 2018 & 2017 & 2018 & 2017 & 2018 & $\begin{array}{c}\text { Pooled } \\
\text { mean }\end{array}$ & 2017 & 2018 & $\begin{array}{c}\text { Pooled } \\
\text { mean }\end{array}$ \\
\hline Uninoculated control & 3.629 & 3.697 & 1.041 & 1.055 & 39.81 & 40.26 & 40.03 & 16.38 & 16.41 & 16.40 \\
\hline Rhizobium (MR 14) & 4.533 & 4.691 & 1.469 & 1.536 & 53.80 & 54.31 & 54.06 & 25.10 & 25.65 & 25.38 \\
\hline PGPR (NE 10) & 4.179 & 4.305 & 1.215 & 1.268 & 46.71 & 48.42 & 47.56 & 19.79 & 20.53 & 20.16 \\
\hline Rhizobium + PGPR & 4.767 & 4.942 & 1.556 & 1.634 & 56.93 & 59.42 & 58.18 & 27.46 & 28.04 & 27.75 \\
\hline RDF & 4.211 & 4.328 & 1.277 & 1.328 & 51.54 & 53.03 & 52.29 & 22.89 & 22.77 & 22.83 \\
\hline C.D. $(P=0.05)$ & 0.688 & 0.659 & 0.225 & 0.189 & 10.86 & 8.05 & 6.35 & 3.70 & 3.09 & 2.41 \\
\hline
\end{tabular}


increased $\mathrm{N}_{2}$ fixation (Singh and Singh, 2018). The enhancement in $\mathrm{N}$ content and its uptake could also be due to increased Biological $\mathrm{N}_{2}$ fixation and nitrate reductase activities of PGPR, or to the uptake of $\mathrm{NH}_{4}{ }^{+}$and amino acids produced by PGPR (Osman et al. 2010).

\section{$P$ content and uptake}

$P$ content due to different inoculation treatments was significantly higher, by 4.8 to $16.0 \%$ in grain and 14.4 to $28.8 \%$ in straw during $2017-18$ and 5.6 to $18.6 \%$ in grain and 18.0 to $39.1 \%$ in straw during $2018-19$, maximum being with the combined inoculation of Rhizobium + PGPR in both the years (Table 5). This trend of $P$ content was also reflected in $\mathrm{P}$ uptake by grain and straw. The maximum mean $\mathrm{P}$ uptake by the grain and straw of both the years was recorded with the dual inoculation of Rhizobium + PGPR, which was significantly more, by 28.1 and $49.0 \%$ over the uninoculated control and 13.5 and $14.0 \%$ over the individual PGPR inoculation. Individual inoculation of Rhizobium and PGPR registered significant increases in mean $P$ uptake of 11.7 and $12.8 \%$ by grain and 25.2 and $30.7 \%$ by straw over the uninoculated control, respectively. Verma et al. (2013) also reported similar increase in $\mathrm{P}$ content and uptake in chickpea following PGPR inoculation due to increased acquisition of $P$ by the plant because of $P$ solubilization in soil and increased root biomass due to PGP activities.

\section{Soil properties}

Different inoculation treatments indicated the non-significant impact on organic $\mathrm{C}$ content in soil after mungbean harvesting (Table 6). Dual inoculation treatment of Rhizobium + PGPR in mungbean resulted significant and highest increase in mineral $\mathrm{N}$, available $\mathrm{N}, \mathrm{P}$ and $\mathrm{K}$ in soil to the tune of $25.8,18.8,57.2$ and $18.7 \%$ over the uninoculated control at crop harvest, respectively (Table 6 and Fig 1). An increase in available $N$ in soil could be ascribed to enhanced $\mathrm{N}_{2}$ fixation by the inoculated

Table 5: Effect of biofertilizer treatments in mungbean on $\mathrm{P}$ content and uptake by mungbean grain and straw.

\begin{tabular}{|c|c|c|c|c|c|c|c|c|c|c|}
\hline \multirow{3}{*}{ Treatment } & \multicolumn{5}{|c|}{$\mathrm{P}$ content $(\%)$} & \multicolumn{4}{|c|}{$\mathrm{P}$ uptake $\left(\mathrm{kg} \mathrm{ha}^{-1}\right)$} & \\
\hline & \multicolumn{2}{|c|}{ Grain } & \multicolumn{2}{|c|}{ Straw } & \multicolumn{3}{|c|}{ Grain } & \multicolumn{3}{|c|}{ Straw } \\
\hline & 2017 & 2018 & 2017 & 2018 & 2017 & 2018 & Pooled mean & 2017 & 2018 & Pooled mean \\
\hline Uninoculated control & 0.331 & 0.338 & 0.125 & 0.133 & 3.63 & 3.69 & 3.66 & 1.97 & 2.07 & 2.02 \\
\hline Rhizobium (MR 14) & 0.347 & 0.357 & 0.143 & 0.157 & 4.07 & 4.12 & 4.09 & 2.44 & 2.62 & 2.53 \\
\hline PGPR (NE 10) & 0.362 & 0.374 & 0.153 & 0.171 & 4.05 & 4.21 & 4.13 & 2.50 & 2.78 & 2.64 \\
\hline Rhizobium +PGPR & 0.384 & 0.401 & 0.161 & 0.185 & 4.57 & 4.82 & 4.69 & 2.84 & 3.18 & 3.01 \\
\hline RDF & 0.352 & 0.361 & 0.147 & 0.158 & 4.28 & 4.43 & 4.35 & 2.65 & 2.70 & 2.68 \\
\hline C.D. $(P=0.05)$ & 0.017 & 0.018 & 0.018 & 0.023 & 0.40 & 0.31 & 0.25 & 0.40 & 0.47 & 0.27 \\
\hline
\end{tabular}

Table 6: Effect of biofertilizer treatments in mungbean on soil organic $\mathrm{C}$ and mineral $\mathrm{N}$ at crop harvest.

\begin{tabular}{lcccccc}
\hline \multirow{2}{*}{ Treatment } & \multicolumn{3}{c}{ Organic C $\left(\mathrm{g} \mathrm{kg}^{-1}\right)$} & \multicolumn{3}{c}{ Mineral N $\left(\mu \mathrm{g} \mathrm{g}{ }^{-1}\right.$ soil) } \\
\cline { 2 - 7 } & 2017 & 2018 & Pooled mean & 2017 & 2018 & Pooled mean \\
\hline Uninoculated control & 8.2 & 8.4 & 8.3 & 45.1 & 46.6 & 45.8 \\
Rhizobium (MR 14) & 8.3 & 8.3 & 8.3 & 53.0 & 55.9 & 54.5 \\
PGPR (NE 10) & 8.2 & 8.1 & 8.2 & 47.2 & 47.7 & 47.4 \\
Rhizobium + PGPR & 8.4 & 8.5 & 8.5 & 56.2 & 59.0 & 57.6 \\
RDF & 8.3 & 8.3 & 8.4 & 51.1 & 51.7 & 51.4 \\
C.D. (P=0.05) & NS & NS & NS & $\mathbf{4 . 7}$ & $\mathbf{5 . 4}$ & $\mathbf{4 . 1}$ \\
\hline
\end{tabular}

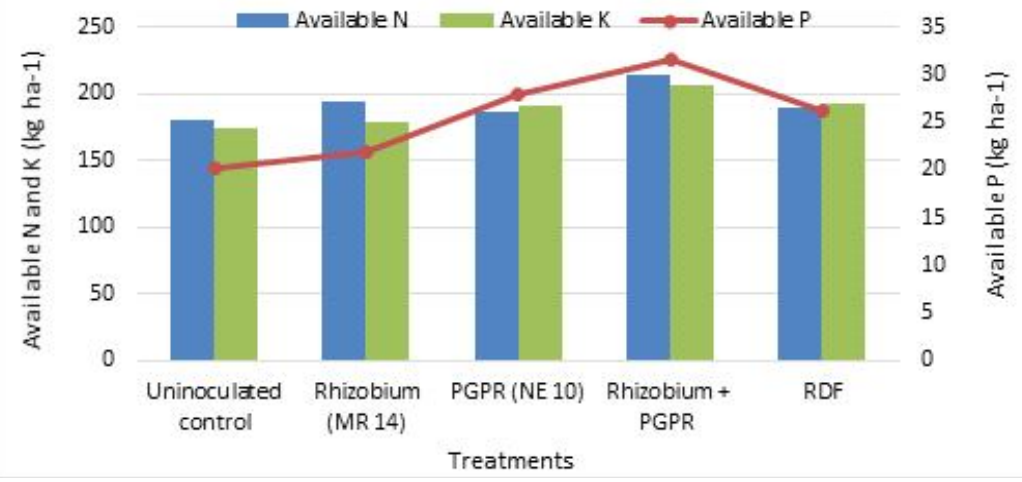

Fig 1: Effect of biofertilizer treatments in mungbean on mean available $\mathrm{N}, \mathrm{P}$ and $\mathrm{K}$ in soil $\left(\mathrm{kg} \mathrm{ha}^{-1}\right)$ at harvest. 
Table 7: Effect of biofertilizer treatments on economics of mungbean cultivation.

\begin{tabular}{|c|c|c|c|c|c|c|c|c|c|}
\hline \multirow[b]{2}{*}{ Treatment } & \multicolumn{3}{|c|}{ Gross return (Rs. ha- $\left.{ }^{-1}\right)$} & \multicolumn{3}{|c|}{ Net return (Rs. ha-1) } & \multicolumn{3}{|c|}{$\mathrm{B}: \mathrm{C}$ ratio } \\
\hline & $2017-18$ & 2018-19 & $\begin{array}{l}\text { Pooled } \\
\text { mean }\end{array}$ & $2017-18$ & 2018-19 & $\begin{array}{l}\text { Pooled } \\
\text { mean }\end{array}$ & $2017-18$ & 2018-19 & $\begin{array}{l}\text { Pooled } \\
\text { mean }\end{array}$ \\
\hline Uninoculated control & 79652 & 97514 & 88583 & 57039 & 74354 & 65697 & 2.52 & 3.21 & 2.87 \\
\hline Rhizobium (MR 14) & 85518 & 103419 & 94468 & 62805 & 80159 & 71482 & 2.77 & 3.45 & 3.11 \\
\hline PGPR (NE 10) & 81403 & 100777 & 91090 & 58690 & 77517 & 68103 & 2.58 & 3.33 & 2.96 \\
\hline Rhizobium + PGPR & 86918 & 107373 & 97146 & 64155 & 84063 & 74109 & 2.82 & 3.61 & 3.21 \\
\hline RDF & 88960 & 109224 & 99092 & 63476 & 83164 & 73320 & 2.49 & 3.19 & 2.84 \\
\hline C.D. $(P=0.05)$ & NS & 7916 & 4221 & NS & NS & 4219 & - & - & - \\
\hline
\end{tabular}

Rhizobium sp. and available $\mathrm{P}$ and $\mathrm{K}$ through solubilization in soil by the PGPR. Co-inoculation consequently led to greater $\mathrm{N}_{2}$ fixation and $P$ solubilization due to the release of protons by Rhizobium during BNF and also by synthesizing various organic acids resulted into lowering of the soil $\mathrm{pH}$ (Khan et al. 2006). Kaur et al. (2015) also reported similar positive effects of Rhizobium + PGPR inoculation on soil chemical properties due to their interactive effect and stated that these inoculants mediated the number of soil processes and thus enhanced the availability of various nutrients.

\section{Economics}

The mean gross and net returns of both the years varied significantly due to different treatments in mungbean (Table 7). The maximum gross return of Rs. 99,092 ha-1 was obtained with application of RDF treatment, however, it was at par with Rhizobium + PGPR treatment. In contrast, the maximum net return of Rs.74,109 ha-1 was observed with dual inoculation of Rhizobium + PGPR, which was Rs. 8,412 ha-1 more than the uninoculated control. This treatment also gave the highest $\mathrm{B}: \mathrm{C}$ ratio of 3.21 in comparison to 2.84 of RDF treatment. These results are in agreement of the findings of Biswas et al. (2012) and Kumawat et al. (2019) and may be attributed to enhancement in the plant nutrient availability in soil resulting in improved growth and yield attributes leading to higher grain yield and gross and net returns.

\section{CONCLUSION}

It could be concluded from the study that combined application of Rhizobium and PGPR in mungbean is superior to individual inoculation of Rhizobium or PGPR in improving the productivity and profitability. It also had positive impacts on the soil fertility and soil biological properties. Results suggested that use of biofertilizers in grain legumes have promise to minimize the plant nutrient related shortcomings of grain legumes production.

\section{REFERENCES}

Anonymous (2019). Project coordinator report (mungbean and urdbean). All India Coordinated Research Project on MullaRP. ICAR-Indian Institute of Pulses Research. pp. 35-37.

Bansal, R.K. (2009). Synergistic effect of Rhizobium, PSB and PGPR on nodulation and grain yield of mungbean. Journal of Food Legume. 22: 37-39.
Biswas, P.K., Bhowmick, M.K., Malik, G.C., Banerjee, M., Ghosh, G.K. and Mitra, S.R. (2012). Synergistic effect of Rhizobium inoculation with co-inoculants on growth and yield of lentil (Lens culinaris Medikus). International Journal of Bioresource and Stress Management. 3(1): 44-47.

Bhattacharyya, P.N. and Jha, D.K. (2012). Plant growth-promoting rhizobacteria (PGPR): emergence in agriculture. World Journal of Microbiology and Biotechnology. 28: 13271350.

Dudeja, S.S., Singh, N.P., Poonam Sharma, Gupta, S.C., Ramesh Chandra, Bansi Dhar, Bansal, R.K., Brahmaprakash, G.P., Potdukhe, S.R., Gundappagol, R.C., Gaikawad, B.G. and Nagaraj, K.S. (2011). Biofertilizer Technology and Pulse Production. In: Bioaugmentation, Biostimulation and Biocontrol. [A. Singh et al. (Eds.)], Springer-Verlag Berlin Heidelberg. pp 43-63.

Hungria, M., Nogueira, M.A. and Araujo, R.S. (2015). Soybean seed co-inoculation with Bradyrhizobium spp. and Azospirillum brasilense: A new biotechnological tool to improve yield and sustainability. American Journal of Plant Sciences. 6: 811-817.

Joshi, P.K. and Rao, P.P. (2017). Global pulses scenario: status and outlook. Annals of the New York Academy of Sciences. 1392: 6-17.

Kaur, N., Sharma, P. and Sharma, S. (2015). Co-inoculation of Mesorhizobium sp. and plant growth promoting rhizobacteria Pseudomonas sp. as bio-enhancer and bio-fertilizer in chickpea (Cicer arietinum L.). Legume Research-An International Journal. 38: 367-374.

Khan, M.S., Zaidi, A. and Wani, P.A. (2006). Role of phosphatesolubilizing microorganisms in sustainable agriculture-A review. Agronomy for Sustainable Development. 26: 1-15.

Khanna, V. and Sharma, P. (2011). Potential for enhancing lentil (Lens culinaris) productivity by co-inoculation with PSB, plant growth promoting rhizobacteria and Rhizobium. Indian Journal of Agricultural Science. 81: 932-934.

Kumawat, K.C., Sharma, P., Sirari, A., Singh, I., Gill, B.S., Singh, U. and Saharan, K. (2019). Synergism of Pseudomonas aeruginosa (LSE-2) nodule endophyte with Brady rhizobium sp. (LSBR-3) for improving plant growth, nutrient acquisition and soil health in soybean. World Journal of Microbiology and Biotechnology. 35(47): 1-17.

Mondal, M. M. A., Malek, M.A., Sattar, M.A., Puteh, A.B., Rafii, M.Y. and Ismail, M.R. (2013). Response of biofertilizer and Urea on growth and yield of mungbean. Legume Research-An International Journal. 36: 448-452. 
Osman, M.E.H., El-Sheekh, M.M., El-Naggar, A.H., Saly, F. and Gheda, S.F. (2010). Effect of two species of cyanobacteria as biofertilizers on some metabolic activities, growth and yield of pea plant. Biology and Fertility of Soils. 46: 861875.

Page, A.L., Miller, R.H. and Keeney, D.R. (1982). Methods of Soil Analysis. Part 2, Chemical and Microbiological Properties. $2^{\text {nd }}$ Ed. American Society of Agronomy and Soil Science Society of America, Madison, WI.

Rana, M., Chandra, R. and Pareek, N. (2015). Co-inoculation effect of endophytic bacteria with Mesorhizobium sp. in chickpea (Cicer arietinum L.) on nodulation, yield, nutrient uptake and soil biological properties. Journal of the Indian Society of Soil Science. 63(4): 429-435.
Singh, Z. and Singh, G. (2018). Role of Rhizobium in chickpea (Cicer arietinum) production - A review. Agricultural Reviews. 39: 31-39.

Stajkovic, O., Delic, D., Josic, D., Kuzmanovic, D., Rasulic, N. and Vukcevic, K.J. (2011). Improvement of common bean growth by co-inoculation with Rhizobium and plant growthpromoting bacteria. Romanian Biotechnological Letters. 16: $5919-5926$.

Verma, J.P., Yadav, J., Tiwari, K.N. and Kumar, A. (2013). Effect of indigenous Mesorhizobium spp. and plant growth promoting rhizobacteria on yields and nutrients uptake of chickpea (Cicer arietinum L.) under sustainable agriculture. Ecological Engineering. 51: 282-286. 